\title{
Damage Analysis of Elbow Fitting at Condenser Air Conditioning Cooling System
}

\author{
Hari Prastowo ${ }^{1}$, Irfan Syarief ${ }^{2}$, Hamzah Fansyuri $^{3}$
}

\begin{abstract}
With the sudden flow of changes, it will affect the physical condition of the elbow. The flow changes in the elbow will result in changes of flow velocity that affect wall of elbow, the condition will cause erosion corrosion phenomenon. Erosion corrotion is a type of corrosion that uses a mechanical process through the relative movement of the flow and metal. Corrosion erosion can also be caused by impingment corrotion or very rapid flow movement. This study aims to determine the cause of damage elbow by using a CFD simulation and troubleshooting by adding a Vortex Generator or a installed disturber system in the pipeline installation and simulating it again. From the results of research conducted that elbow damage caused by high flow velocity that concerns the outer elbow. The addition of Vortex Generator is proven to be used to reduce excessive flow velocity on erosion-corroded parts. According to the results of the investigation the placement of the most efficient vortex generator if placed at a distance of $0.1 \mathrm{R}$ from elbow inlet.
\end{abstract}

Keywords — computational fluid dynamic (CFD), erosion corrotion, flow velocity, vortex generator.

\section{INTRODUCTION}

$\mathrm{P}$ iping system is a system that serves to flow a fluid from a lower place to a desired destination with the machinery either a pump or a compressor. For example, piping systems used to move fuel or lubricants from tanks to engines, seawater supply systems as coolants, as well as systems for ballast system, and many more examples of piping systems on board Supporting safety operations, as well as support systems for crew activities on board

In planning of piping installation system is expected to produce efficient pipeline installation which in terms of laying and safety aspect in operation must be considered according to the classification rules and from the installation guide specification of machinery support system [1-9]. With the availability of limited space in the vessel, the installation system is expected to run as efficiently as possible. The piping installation system in the vessel use fittings or adding more installations to allow the flowing fluid to reach the desired destination with very minimum space $[2,10-16]$.

The fittings in a piping system installation serve to change direction of flow, spread the flow, increase or

Hari Prastowo, Departmen of Marine Engineering, Institut Teknologi Sepuluh Nopember, Surabaya 60111, Indonesia, Email : hariprastowo@gmail.com

Irfan Syarief, Departmen of Marine Engineering, Institut Teknologi Sepuluh Nopember, Surabaya 60111, Indonesia, Email : Irfansya@gmail.com

Hamzah Fansyuri, Departmen of Marine Engineering, Institut Teknologi Sepuluh Nopember, Surabaya 60111, Indonesia, Email : hamzah.fansyuri13@mhs.ne.its.ac.id decrease the flow. Related to elbow fitting in this research will be disscuded about damage of Elbow fittings (bend) on condenser air conditioning cooling system in ship of Indonesian Navy.

The condenser is a part of the refrigeration that receives the vapor from high pressure and hight temperature refrigerant from the compressor and removes the heat condensat by cooling the high pressure and hight temperature refrigerant vapor to its dew point by removing its sensible heat [3]. In this case the type of condenser used is a double pipe type with a sea water as a refrigerant cooler.

Elbow fittings is a fitting that serves as a flow change in a piping system installation. The damage demage of elbow fitting is due to the hight flow velocity affecting thewall of elbow. It is commonly known by the corrosion erosion or corrosion due to the very rapid fluid flow affecting the metal wall [4, 17-20].

Based on the existing problems, in this research will be discussed about flow analysis that occurred in the fitting and problem solving method to solve the problem.

\section{METHOD}

The methodology used in this study is a simulation based method, which will be tested using software according to the specification of the existing system which then the results of the simulation will be used as a reference for solving a problems. This methodology covers all activities that will be carried out to solve the problem or do the analysis process in this problem. For more details will be described as follows:

\section{A. Problem Identification}

This thesis writing begins with identifying and formulating problems regarding the work to be done as well as the limitations of the problem. This is to simplify the problem so as to facilitate the work and completion of this research. 


\section{B. Study of Literature}

Collection of references materials that support this research activity, that is about erosion corrosion and process of happening, influence of flow rate to erosion corrosion, previous research which discuss about corrosion of eriosi, and Computational Fluid Dynamic (CFD).

\section{Data Collection}

The collection of supporting data to assist in the process of research is related to the specification of the system experiencing problems such as pump specifications, pipe diameter, radius and diameter off elbow, Pump and pipe location.

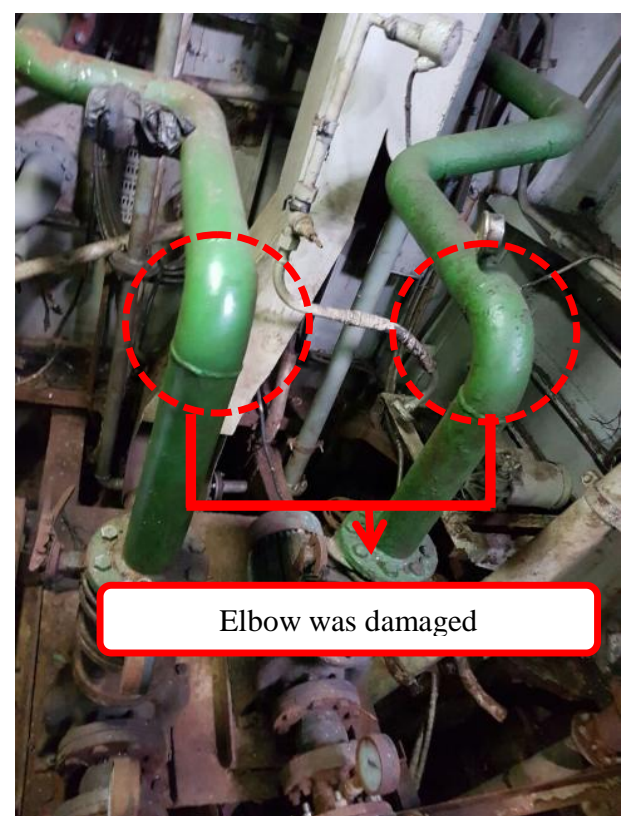

Figure. 1. Elbow in condenser air conditioner cooling system in ship of TNI Navy

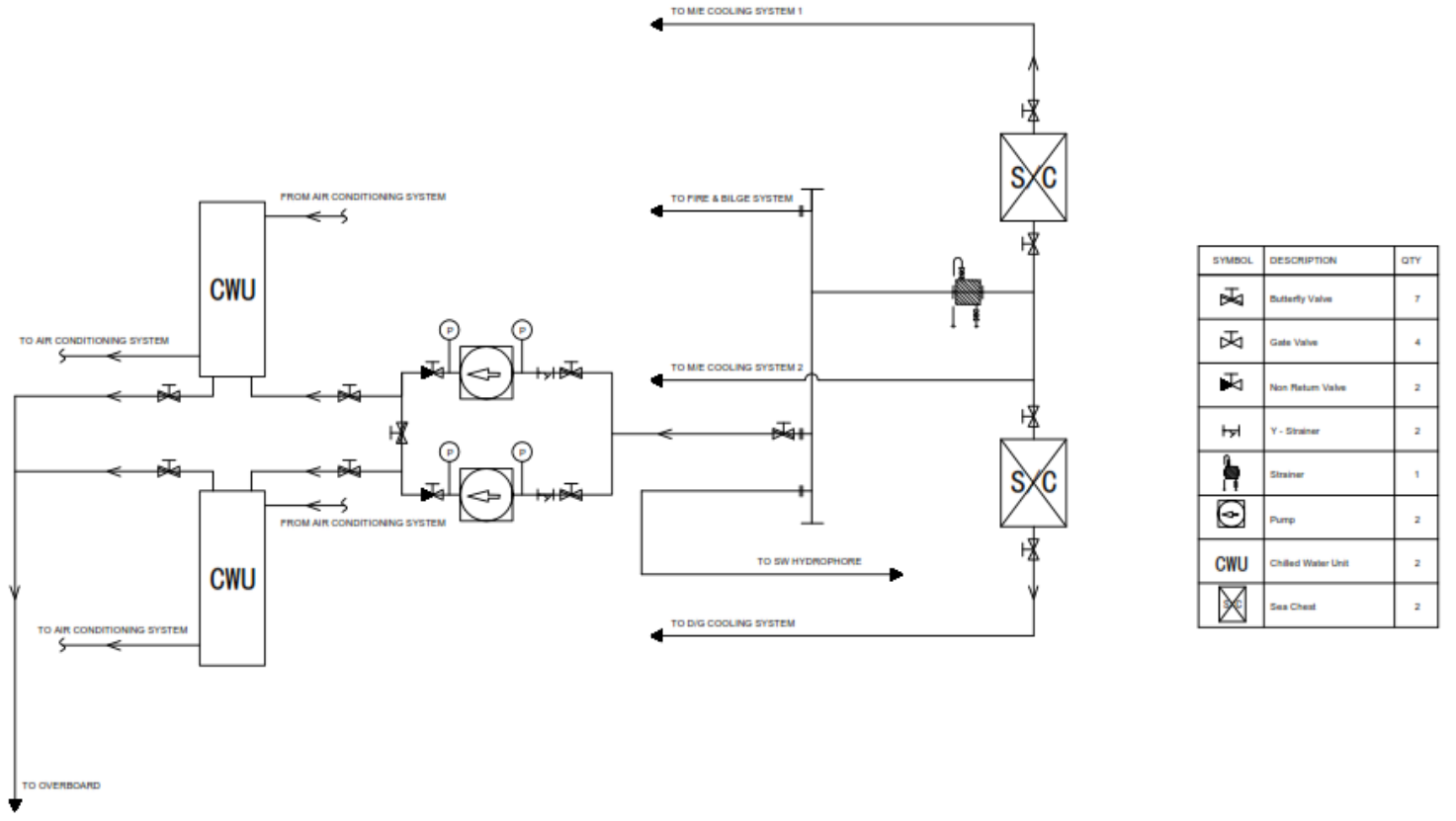

Figure. 2. P\&ID system in condenser air conditioner cooling system in TNI - Navy Vessel

Figure 1. is an elbow that often suffered damage that has been repaired. Figure 2 is a picture of the Key Plan condenser air conditioner cooling system on a ship of Indonesian Navy. The condenser cooling system uses a seawater for condenser cooler. The location of the problem lies on the discharge side of the pump to condenser or CWU (Chilled Water Unit) [5].

The technical specifications data of the system will be explained in table 1 and table 2 . In the table will be described the cooler pump specifications, pipe dimensions and pipe locations 
TABLE. 1.

PIPING SYSTEM SPECIFICATION OF CONDENSER AIR CONDITIONER COOLING SYSTEM

\begin{tabular}{lr} 
Pipe Specification & \\
\hline Nominal Pipe Size & $2 \frac{1 / 2}{\mathrm{In}}$ \\
Outside Diameter & $3 \mathrm{In}(76.3 \mathrm{~mm})$ \\
Wall Thickness & 0.276 in $(7.0 \mathrm{~mm})$ \\
Inside Diameter & $62.3 \mathrm{~mm}$ \\
Schedule & 80 \\
\hline & (Standart JIS G 3456) \\
\hline Radius of Elbow & $114 \mathrm{~mm}$ \\
Hight & (Standart ANSI B16.9) \\
& $500 \mathrm{~mm}$ \\
\hline
\end{tabular}

TABLE. 2.

PUMP SPECIFICATION OF CONDENSER AIR CONDITIONER COOLING SYSTEM

\begin{tabular}{lr}
\hline Pump Specification & \\
\hline Brand & SihiZLKCD 65-12 \\
Qapacity $(l t /$ menit $)$ & 740 \\
Qapacity $(\mathrm{m} 3 / \mathrm{h})$ & 44.4 \\
Head $(\mathrm{m})$ & Max 90 \\
RPM & 3600 \\
\hline Motor & \\
\hline Brand & AEG Hamburg \\
Power & 4.4 KW/380 V AC/50 HZ \\
\hline
\end{tabular}

\section{Drawing Model}

The modeling of this simulation using Solid Works 2012. The model consists of three models, one standard model and two modified models. Standard model (Figure 3 ) is made to know the problems that occur on the system, and than the modified model made to solve problems that occur in the standard model.

Modification of the model that will be done is to add a disturb flow or often known as Vortex Generator
(VG). The first modified VG will be placed on the elbow inlet and the modification of the two models will be placed at $0.1 \mathrm{R}$ addition of the distance from the elbow inlet.

The model and dimensions of the vortex generator refer to the research by Lijun Wang ${ }^{[6]}$ which also refers to research by Panaras, A.G ${ }^{[7]}$

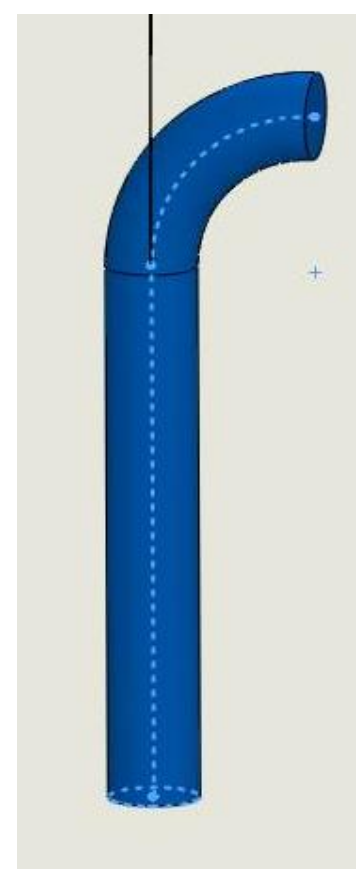

Figure. 3. Model of elbow standart 


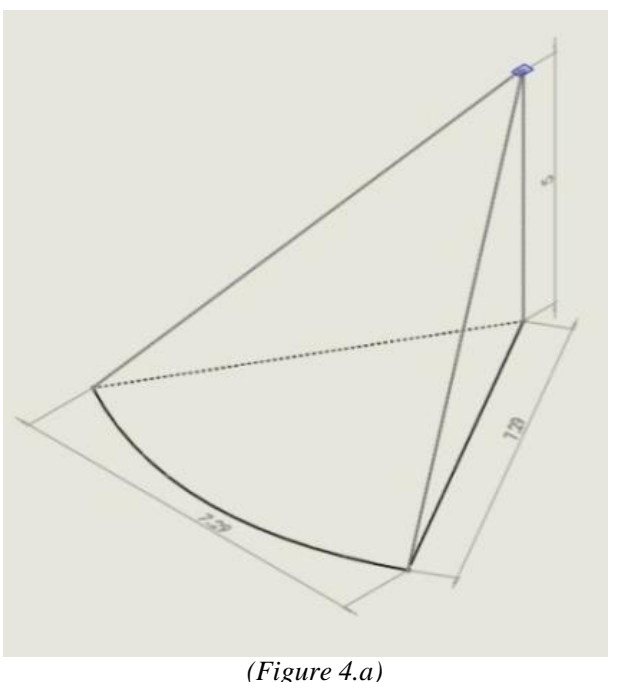

(Figure 4.a)
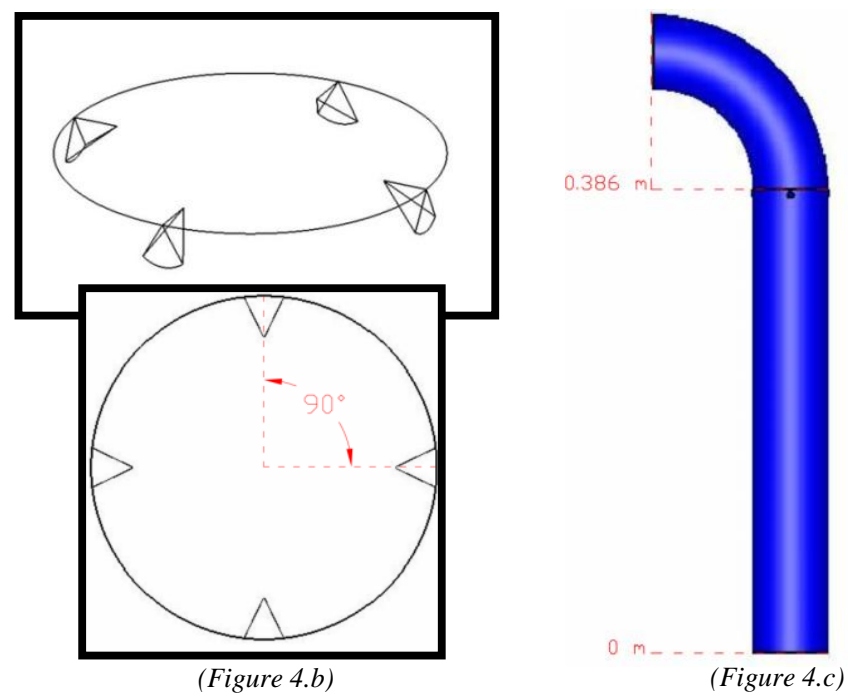

Figure. 4. Elbow model with vortex generator

\section{E. Simulation}

At this experiment will be done a simulation to know the flow conditions that exist in the system. Results of the simulation will be known as a pressure and flow rate on the system. Simulation on this research will be done by using software Numeca Fine Open Student Version lisension.

Corrosion erosion is a type of corrosion that uses a mechanical process through the relative movement between gas flow or corrosive fluid with metal. In this case the destruction due to erosion and corrosion support each other. Metals that have been exposed to erosion became sharp and rough. These parts are vulnerable to corrosion and if there is friction will cause more severe abrasion and so on. Corrosion erosion can also be caused by impingment corrosion, which is caused by a very heavy fluid and can decrease protective film on metal which leads to corrosion of the metal [2]. Corrosion erosion can be found in the piping system (especially on bend, elbow, and joint), valve, pump, nozzle, heat exchangers, turbine blades etc.

The process of erosion corrosion in generaly is through some of the following stages:

1. In the first stage there is an attack by a very rapid flow that will decreasev the protective layer of metal.

2. In the second stage there will be a rough section on the metal surface.
3. In the third stage, the corrosion rate increases, because the protective layer has disappeared. The metal under the protective layer starts to corrodate, thus forming the basin, then reshaping the protective layer and the metal becomes uneven. When the flow continues to flow, it will happen attack by bubbles of air carried by the flow. This attack will erode and damage the newly formed protective layer, damage to the protective layer will result in further attacks on the deeper metal to became a basin $^{[2]}$

The velociy of the fluid is very influential on the erosion-corrosion. Events of erosion-corrosion are determined by fluid velocity, Corrosion will be more dominant if fluid velocity is very slow, this is because of the length of contact time, if the fluid velocity is very high the erotion will be more dominant [6].

The amount of fluid velocity is very influential on the form of damage that occurs in the workpiece. At a relatively low velocity will cause pitting corrosion (Figure 5). While at high speeds, the form of damage occurring on the inner surface of the pipe will result in damage to the horseshoe (Figure 6). 

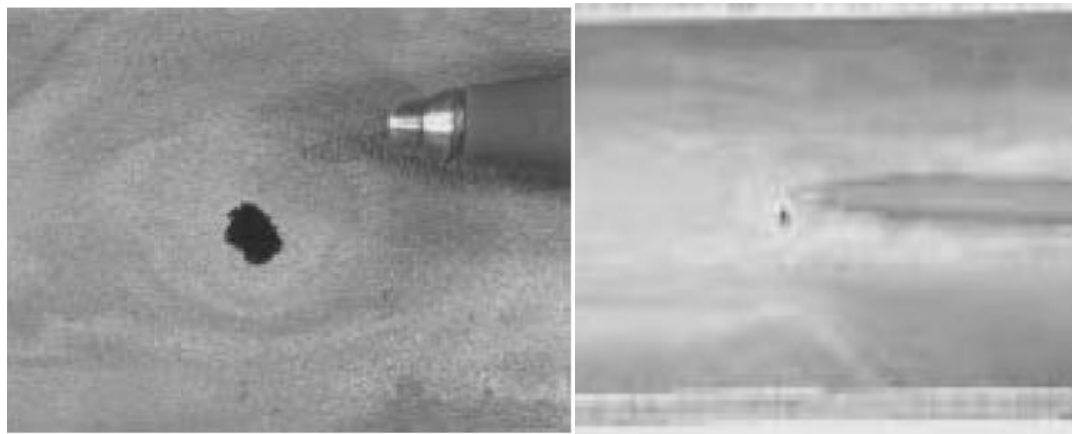

Figure. 5. Pieces of stainless pipe pitting ${ }^{[3]}$

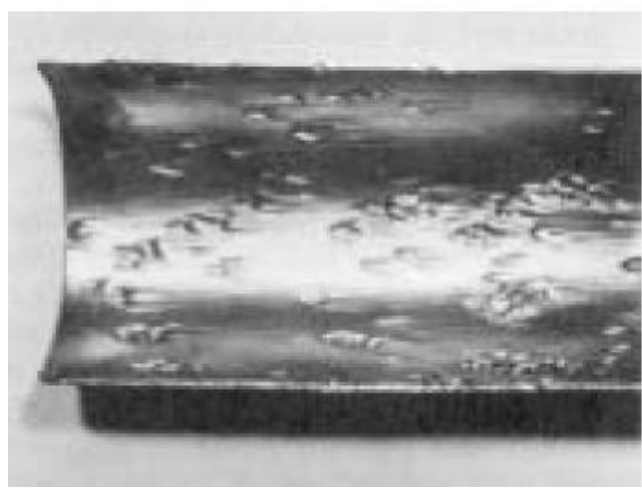

Figure. 6. Pieces of pipe horseshoe ${ }^{[3]}$

Based on the results of existing studies related to the effect of flow velocity on the rate of erosion by modeling CFDs that have been done by Abrorul Fuady R., MSK. Tony SU., Eflita Yohana with the title "Analisa pengaruh jarak choke bean terhadap laju erosi aliran dua fasa steam-solid di dalam elbow pada pipa vertical injector uap PT. Chevron Pasific Indonesia
(CPI) menggunakan $C F D^{\text {,[5] }}$ As well as research ever conducted by Chen $\mathrm{X}$ with the title "Application and exsperimental validation of a computational fluid dynamics (CFD) based erosion prediction model in elbow and plugged tees",[6] In 2004 obtained the following results:

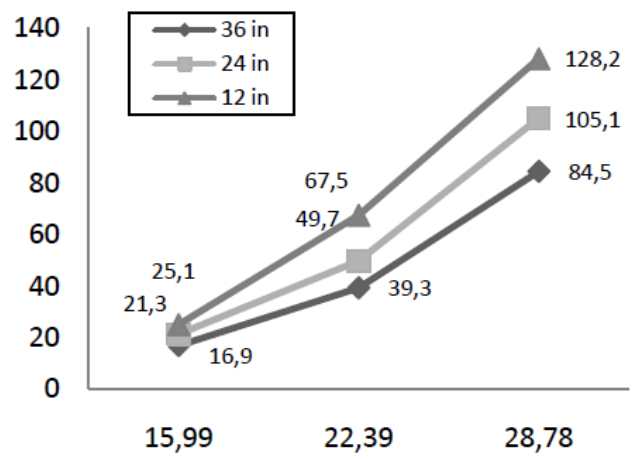

Figure. 7. Graph of steam velocity and erotion rate ${ }^{[6]}$

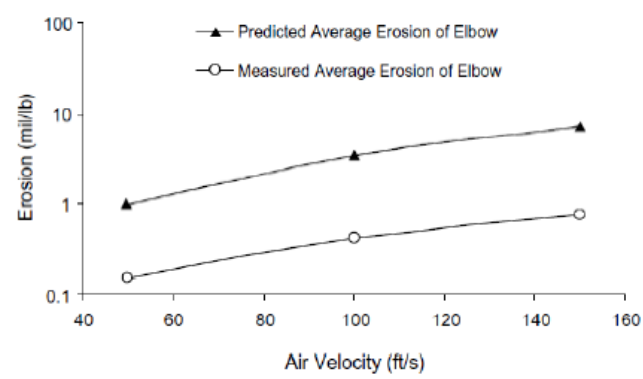

Figure. 8. Graphof fluid velocity (air) and erotion rate ${ }^{[6]}$ 
Computational Fluid Dynamics (CFD) is one of the branches of fluid mechanics that uses numerical methods and algorithms to solve and analyze problems related to fluid flow. Steps of Computational Fluid Dynamics consists of three main elements:

1. Pre Processor

2. Solver Manager

3. Post Processor

\section{RESULTS AND DISCUSSION}

The results obtained from the simulation process will be the flow velocity and pressure on the system. From these results will be reviewed further based on existing theories related to the phenomenon of erosion corrosion on pipes. This result is the analysis based on simulation.

\section{A. Result of simulation elbow standart model}

From Figure 9 we can see that the contour of flow velocity with the highest value occurs in the elbow section when compared to the velocity conditions in the other parts of the model. From the initial system velocity of the system is $4.05 \mathrm{~m} / \mathrm{s}$, at the elbow increases to about $6-8 \mathrm{~m} / \mathrm{s}$. This condition is in accordance with the existing theory which explains that the phenomenon of erosion corrosion is generally common in parts or areas around the pipe installation, one of which is the bend pipe or elbow section of the pipe fitting

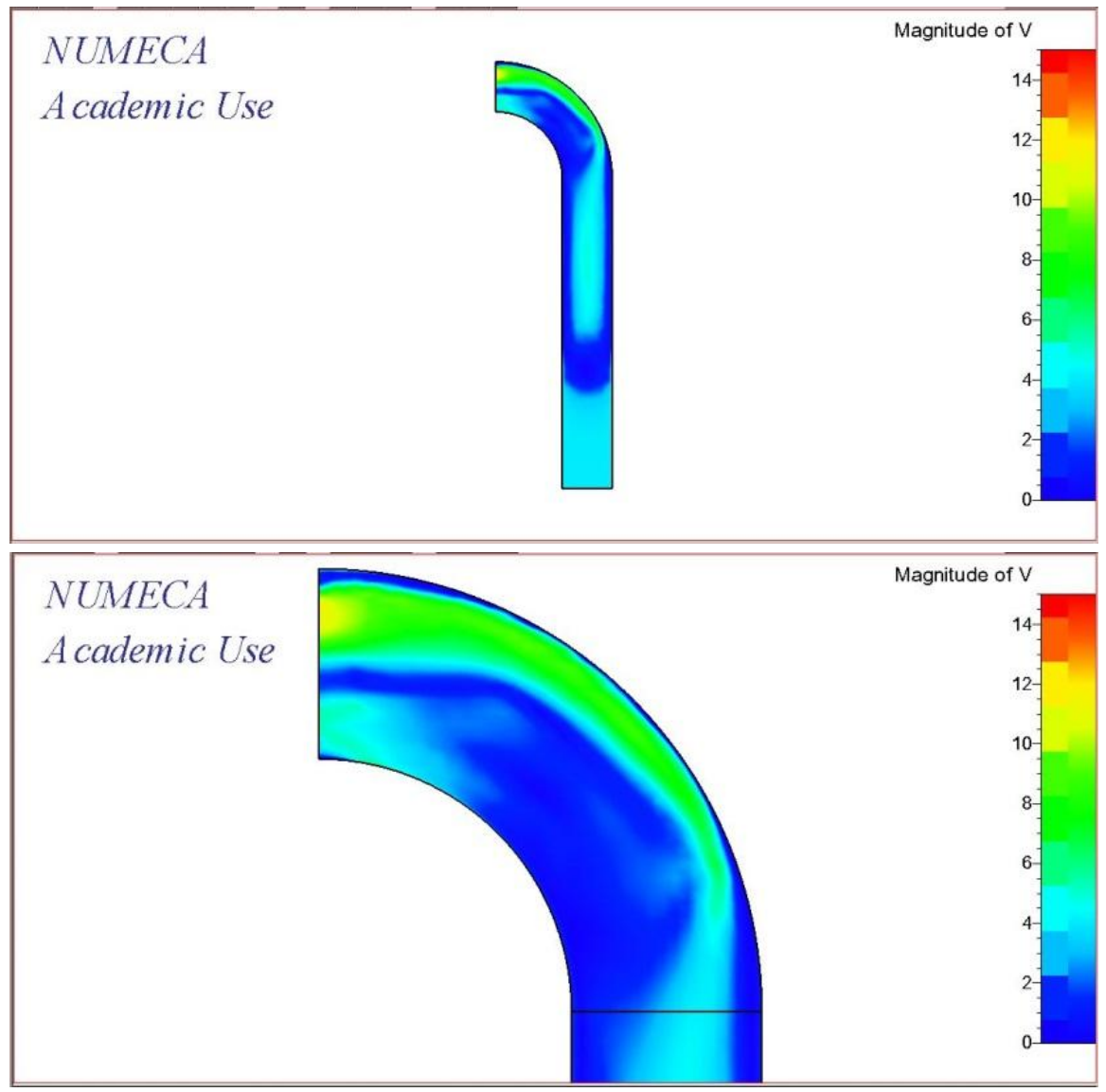

Figure. 9. Result of fluid velocity at elbow standart model

From Figure 9 it can be seen that the highest flow velocity conditions in the elbow occur in the outer elbow or the outer side of the elbow. While on the inside of the elbow or inner elbow tends to decrease the speed of the system work speed.

In the figure also shows that the frequent of erosion corrosion in the elbow that causes damage of elbow fittings in almost installation piping system.

Figure 10 shows the ratio of flow velocity and pressure to the elbow. Based on existing theory that relation of flow velocity and pressure is inversely proportional, where for areas with high flow velocity value it will have a relatively lower pressure value and than when the area with low flow felocity it will have a higher pressure. But from the above comparison the area with high flow velocity value also has a high pressure value, it indicates if there is a mistake to the system. 

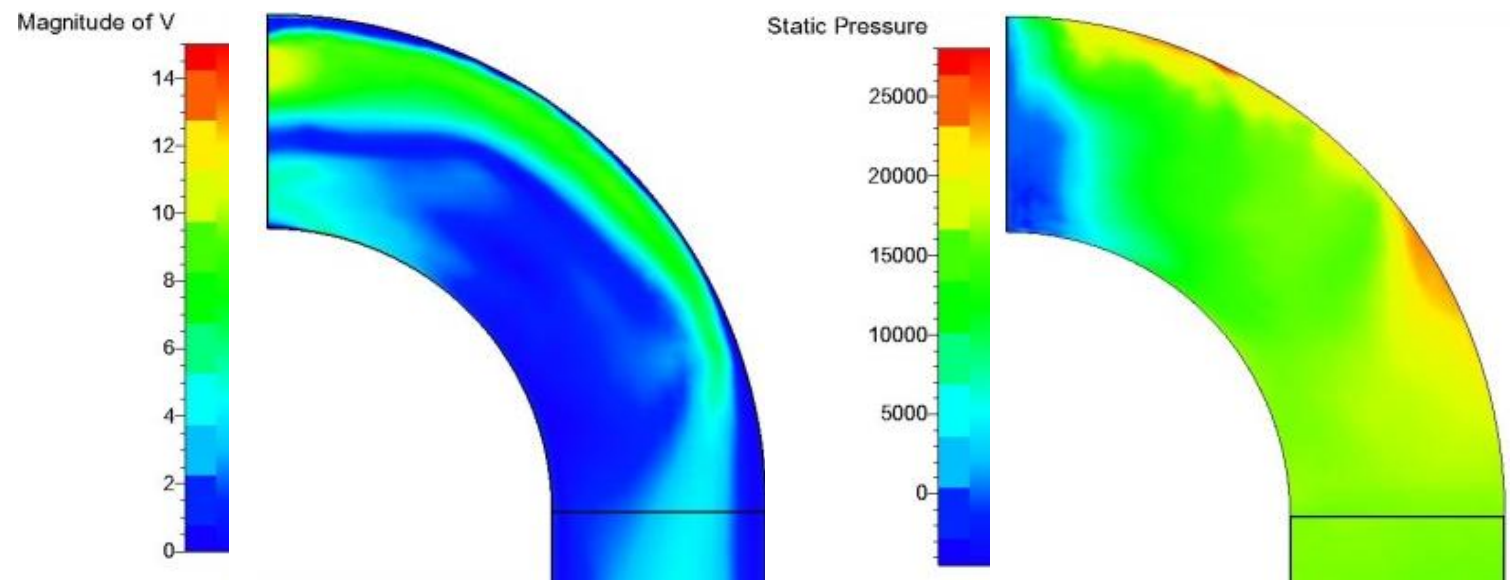

Figure. 10. Comparration of fluid velocity and pressure atelbow standart model

B. Result of simulation modification elbow model Based on the existing problems attached to elbow damage caused by the erosion corrosion phenomenon or damage caused by high flow velocity on the outer elbow side then the next analysis is the effect of adding vortex generator to reduce the hight flow velocity in areas with high flow velocity at outer elbow .
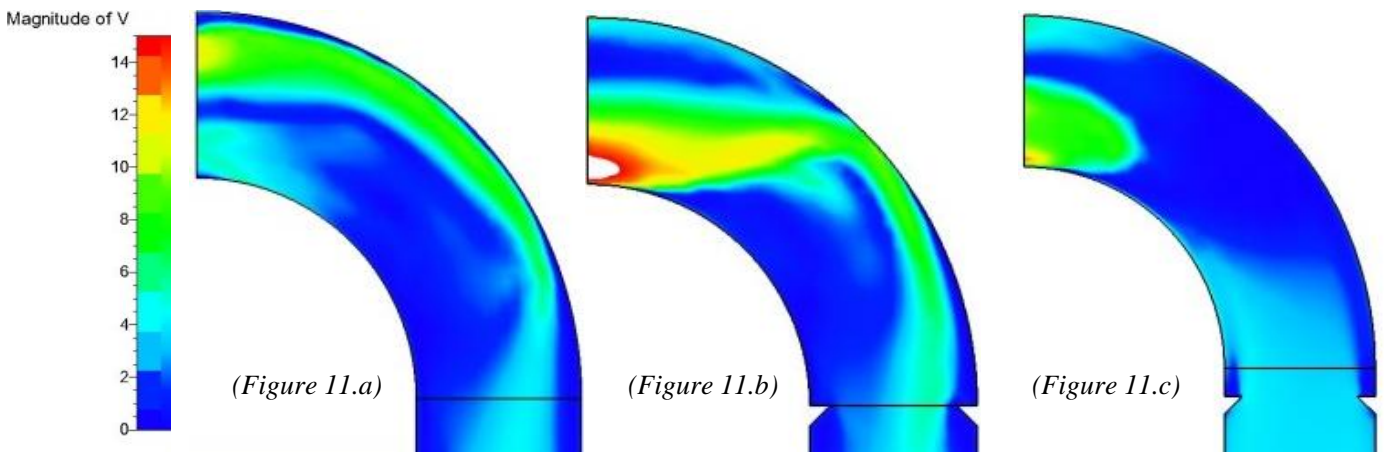

Figure. 11. Fluid velocity contour in elbow standart model(11.a), elbow with modification type 1 1(11.b), elbow with modification type 2 (11.c)

From figure 11 can be seen contour of flow velocity on three elbow model. 11.b is an elbow with a modified vortex generator placed on an elbow inlet, and an image of $11 \mathrm{c}$ is an elbow with modification using a vortex generator at the addition of $0.1 \mathrm{R}$ distance from the first modification.

In figure 11.a, the high flow velocity at outer elbow has a flow rate value of $6-8 \mathrm{~m} / \mathrm{s}$. In Fig. 11.b or on the modification of both areas the erosion corrosion can be reduced but with a fixed flow rate trend in the original condition. In the third modification or in figure 11.c the area with high flow velocity on the elbow can be completely reduced.

In the next analysis will be shown the contours of elbow pieces to further clarify the flow rate contours that occur in the elbow before and after the addition of a vortex generator.

Figure 12 describes the cut scenario on the elbow. For the first cut distance lies in the flow velocity conditions before entering the elbow fittings. For other pieces will be done in the elbow area with the provision of the center of the rotary axis is located right on the elbow radius of $114 \mathrm{~mm}(0.114 \mathrm{~m})$ with a rotary angle of $18^{0}$ to reach the turning angle of $90^{\circ}$ or just on the outlet side of the model. To be more specific here is an explanation of the position on each piece.

$>$ Pieces $1=326 \mathrm{~mm}(0.326 \mathrm{~m})$ from the inlet side Model or $0 \mathrm{~m}$ model.

$>$ Pieces $2=$ At the center of the elbow radius with Turning corner $0^{0}$

$>$ Pieces $3=$ At the center of the elbow radius with $18^{0}$ turning angle

$>$ Pieces $=$ At the center of the elbow radius with $36^{0}$ rotary angle

$>$ Pieces $5=$ At the center of the elbow radius with Turning corner $54^{0}$

$>$ Pieces $6=$ At the center of the elbow radius with Turning corner $72^{0}$

$>$ Pieces $7=$ At the center of the elbow radius with $90^{\circ}$ turning angle 


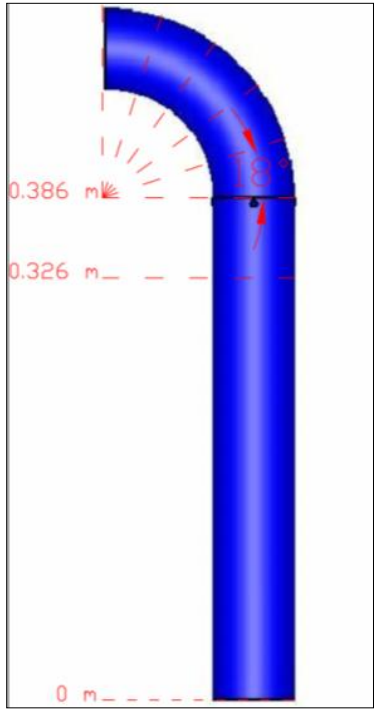

Figure. 12. Planing of piece elbow model

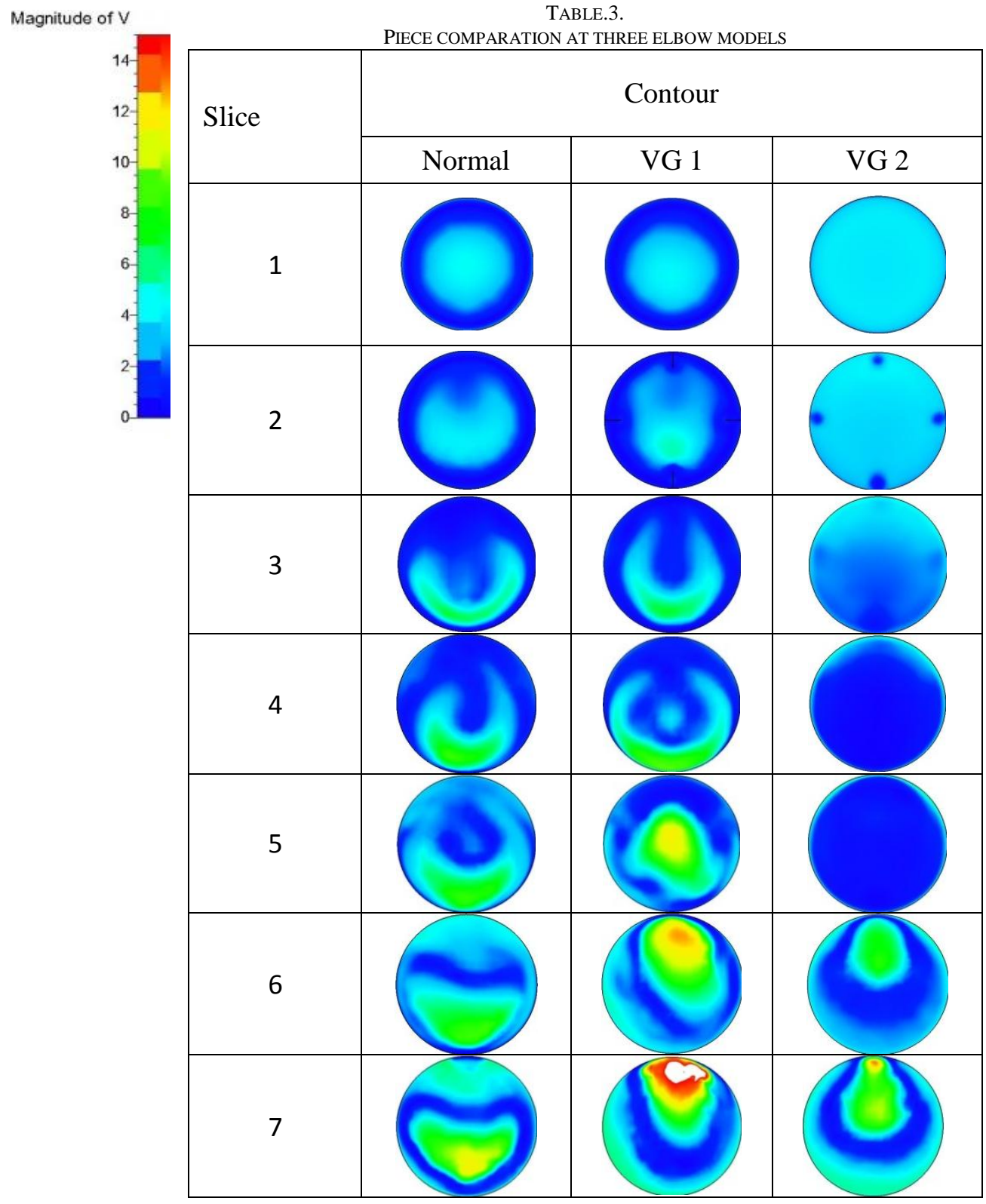


From table 3 can be seen the contour flow velocity on seven pieces of elbow with three models of different elbow variations. In Figure $\mathbf{1 1}$ it is well known that the most effective Vortex Generator (VG) placement to solve the erosion corrosion problem in the system is if VG is placed on a third elbow modification with a further $0.1 \mathrm{R}$ placement of the first modification.
The critical area of erosion of the simulated results is in pieces 4 and 5 in the standard model. Compared to the three model conditions, at pieces 4 and 5 it is clear that changes in flow velocity, especially on the critical side of corrosion erosion in the outer elbow.

The change in flow velocity on the critical side will be further clarified with the analysis of the flow velocity graph on this piece.
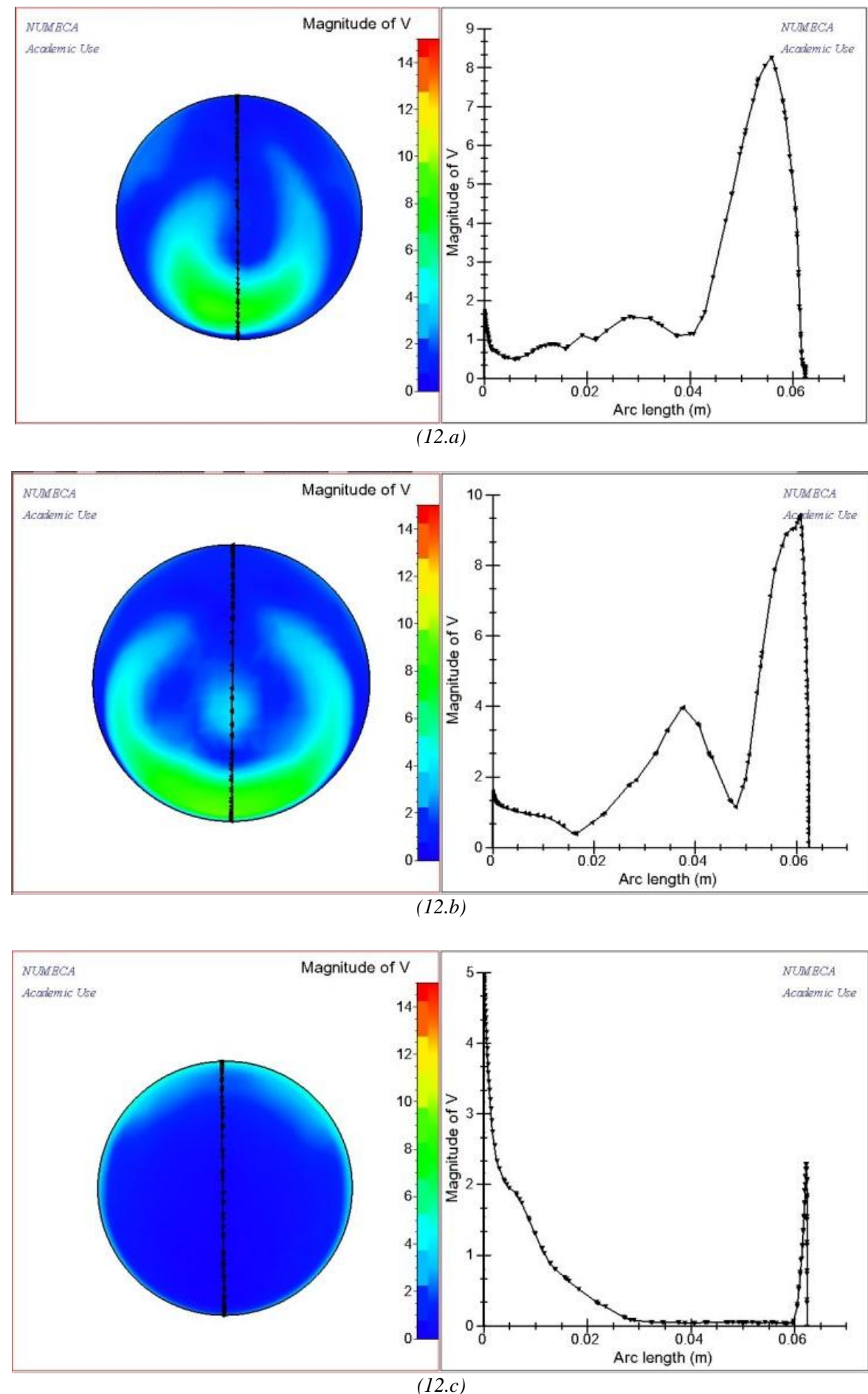

Figure. 12. Fluid velocity three elbow models at $4^{\text {th }}$ of piece

Figure 12 illustrates the flow velocity cuts and graphs at the vertical points of the piece. From the standard pipe cutting image (12.a) it can be analyzed that the highest flow velocity contours are at points with a distance of $0.055 \mathrm{~mm}$ to $0.0623 \mathrm{~mm}$ in the inside diameter of pipe. The flow velocity at that point ranges 
from 8-9 $\mathrm{m} / \mathrm{s}$. With the addition of a vortex generator at a distance $\mathrm{R}$ or at an elbow radius the flow velocity at that point tends not to change with a relatively equal velocity condition, but when the vortex generator is placed at a distance of $0.1 \mathrm{R}$ from the inlet elbow position the high flow velocity condition at that point Can be reduced.
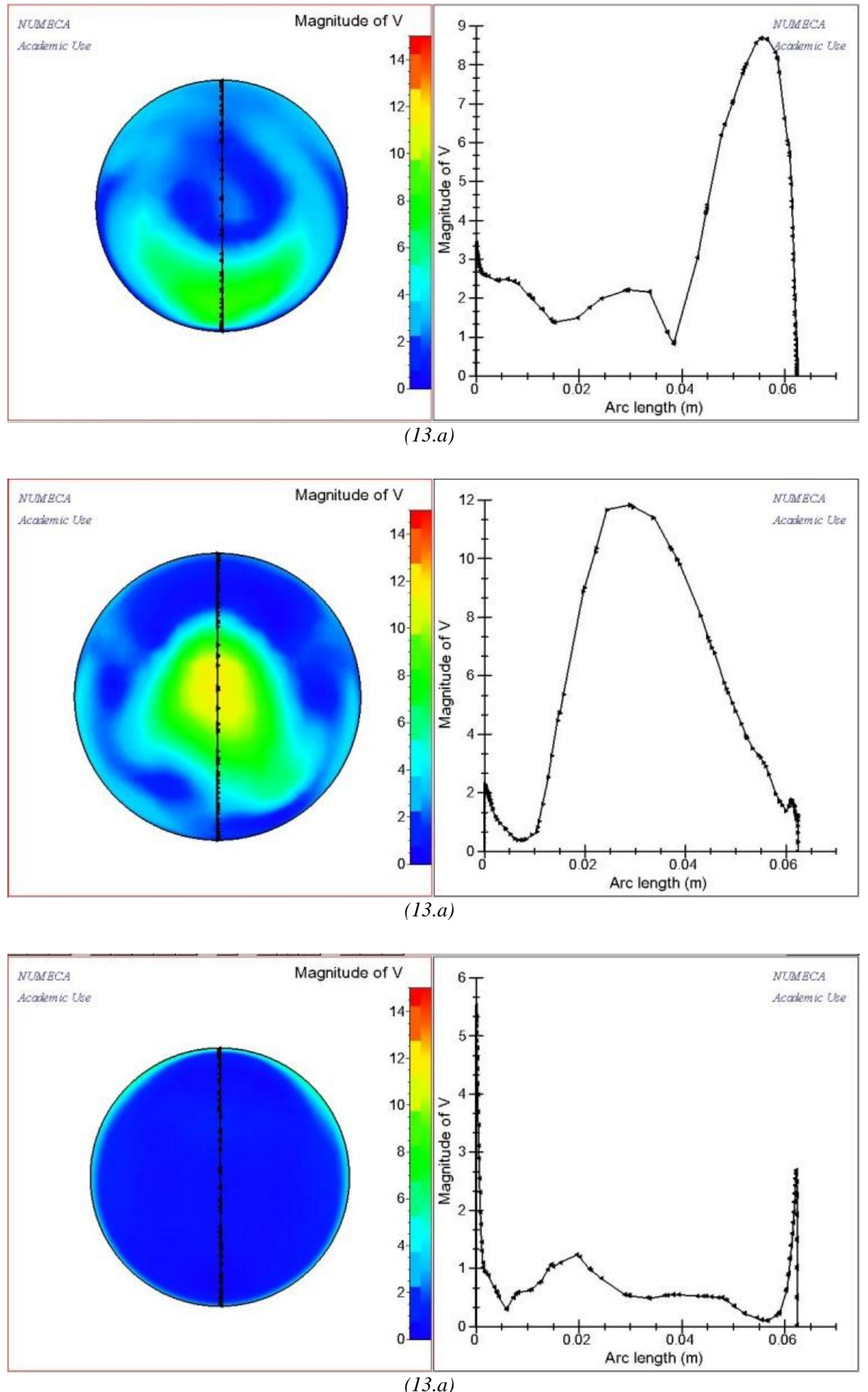

Figure. 13. Fluid velocity three elbow models at $5^{\text {th }}$ of piece

The flow velocity in the standard elbow model on the fifth piece (13.a) tends to increase the flow velocity to a speed of $9 \mathrm{~m} / \mathrm{s}$ in the same position as the previous analysis. For the flow velocity of the model with the addition of the vortex generator at a distance $\mathrm{R}$ tends to decrease up to $3.5 \mathrm{~m} / \mathrm{s}$ in the same area, but there is an increase in flow velocity at the center of the pipe radius. Similar to the previous condition that in the fourth piece the addition of a vortex generator at a distance of $0.1 \mathrm{R}$ 
from the elbow radius is shown to reduce the high flow velocity in the area.

\section{CONCLUSION}

Based on the results of simulation and analysis that has been done with the ultimate goal of modifying the system to solving the problem of elbow damage, it can be concluded that:

1. From the simulation results can be seen that the elbow damage occurs because of the flow velocity of system on the outer elbow which is often called the phenomenon of erosion corrosion. Because of the high speed, the flow will erode the protective layer of the pipe so that will caused a sharp part that is very influential on the emergence of corrosion.

2. The addition of Vortex Generator or flow disturber has been shown to reduce excessive flow rate in the affected part of erosion corrosion.

3. Vortex Generator laying has the most efficient result to solve the problem of corrosion erosion on the vertical pipe when placed at a distance of $0.1 \mathrm{R}$ before the elbow radius assuming $\mathrm{R}$ is the radius of the elbow.

\section{REFERENCES}

[1] Bayuseno,A.B.,Handoko,Erizal Dwi. Analisa Korosi Erosi Pada Baja Karbon Rendah dan Baja Karbon Sedang Akibat Aliran Air Laut.

[2] Tambunan,Mercys Lucya N.,dkk.,(2012).KorosiErosi/Kavitasi, https://id.scribd.com/doc/73060573/KOROSI-EROSI

[3] Somawardi,dkk.,(2006), Pengaruh kecepatan fluida dan konsentrasi $\mathrm{NaCl}$ terhadap kerusakan material dalam bentuk korosi

[4] Andira mulia siregar,Muhammad.,(2013),Tentang CFD (Computational Fluid Dynamic).

[5] Fady R, Abrorul.,dkk.,(2015), Analisa pengaruh jarak choke bean terhadap laju erosi aliran dua fasa steam-solid didalam elbow pada pipa vertikal injektor uap pt. Chevron Pasific Indonesia (CPI) menggunakan CFD. Fakultas Teknik,Universitas Diponegoro.

[6] Wang,Lijun.,at all., 2016,A Numerical study on efficient recovery of fine-grained minerals with vortex generators in pipe flow unit of a cyclonic-statis micro bubble flotation column. China University of Mining, Jiangsu,China.

[7] Panaras,A.G.,LU,F.K., 2015. Micro-vortex generator for shock wave/boundary layer interaction. Prog. Aerosp. Sci. 74, 16-47

[8] Chen, X.,at all., 2004, Application and experimental validation of a computational fluid dynamics (CFD)-based erosion prediction model in elbows and plugged tees, Computers \& Fluids 33 12511272.

[9] Adhika Pandyo, Nityoga.,(2012)Studi pengaruh Ph lingkungan 4 terhadap laju korosi baja karbon API $5 L$ X-52 sebagai pipa penyalur proses produksi gas alam yang mengandung gas $\mathrm{CO}_{2}$ pada larutan $\mathrm{NaCl} 3.5 \%$ dengan variasi laju aliran. Fakultas Teknik, Universitas Indonesia, Depok.

[10]H. Prastowo, A. Santoso, and A. Arya, "Analysis and Optimation Hydrofoil Supported Catamaran (HYSUCAT) Size 25 Meter based on CFD Method," International Journal of Marine Engineering Innovation and Research., vol. 1, no. 1, Dec. 2016.

[11] A. Baheramsyah, B. Cahyono, and F. S. Aruan, "Slurry Ice as a Cooling System on 30 GT Fishing Vessel," International Journal of Marine Engineering Innovation and Research., vol. 1, no. 3, Jun. 2017.

[12] A. Z. M. Fathallah, W. Busse, and F. R. Clausthaldi, "Fluid Flow Analysis of Jacket Cooling System for Marine Diesel Engine 93 $\mathrm{Kw}$," International Journal of Marine Engineering Innovation and Research., vol. 1, no. 2, Mar. 2017.

[13]A. Z. M. Fathallah and F. H. Husein, "Technical Analysis of Influence of Special Treatment on Water Ballast Treatment by using Active Carbon on Vessel and Environment," Internationa Journal of Marine Engineering Innovation and Research., vol. 1, no. 1 , Dec. 2016.

[14]A. Amiadji, E. Djatmiko, and Y. N. Prasetyo, "Efficiency Analysis of Additions of Ice Flake in Cargo Hold Cooling System of Fishing Vessel," International Journal of Marine Engineering Innovation and Research., vol. 1, no. 3, Jun. 2017.

[15]I. R. Kusuma, "Design and Simulation of Automatic Ballas System on Catamaran Ship Based on Programmable Logic Control," International Journal of Marine Engineering Innovation and Research., vol. 1, no. 3, Jun. 2017.

[16]Semin. (2015). Investigation the Effect of Injector Nozzle Mult Holes Geometry on Fuel Spray Distribution Flow of CNG Engine Based on Computational Modeling. International Journal of Applied Engineering Research 10 (15). pp.36087-36095.

[17] Semin, B Cahyono, Amiadji, RA Bakar, (2015). Air-fuel Mixing and Fuel Flow Velocity Modeling of Multi Holes Injector Nozzle on CNG Marine Engine. Procedia Earth and Planetary Science $14,101-109$.

[18]Semin and R.A. Bakar. (2014). Computational Modelling the Effect of New Injector Nozzle Multi Diameter Holes on Fuel-Air Mixing Homogeneous of CNG Engine. International Journal of Applied Engineering Research. Volume 9 (21). pp. 9983.

[19] Semin and R.A. Bakar. (2013). Simulation and Experimental Method for the Investigation of Compressed Natural Gas Engine Performance. International Review of Mechanical Engineering 7 (7).

[20] Semin (2012) .Injector Nozzle Spray on Compressed Natural Gas Engines: a Technical Review. International Review of Mechanical Engineering, Vol.6 No.5. 